\title{
Transcriptional Response of Mycobacterium tuberculosis to Cigarette Smoke Condensate
}

\section{OPEN ACCESS}

Edited by:

Ramandeep Singh,

Translational Health Science and Technology Institute (THSTI),

India

Reviewed by:

Vikram Saini,

All India Institute of Medical Sciences,

India

G. Marcela Rodriguez, Rutgers University, Newark,

United States

William Bishai,

Johns Hopkins University, United States

*Correspondence:

Deepak Kaushal

dkaushal@txbiomed.org

${ }^{\dagger}$ Present address:

Danicke Willemse,

Division of Pulmonology, Department of Medicine, Observatory, University of Cape Town, Cape Town, South Africa

Specialty section:

This article was submitted to Infectious Agents and Disease,

a section of the journa

Frontiers in Microbiology

Received: 20 July 2021 Accepted: 13 September 2021

Published: 15 October 2021

Citation:

Willemse D, Moodley C, Mehra S and Kaushal D (2021) Transcriptional

Response of Mycobacterium

tuberculosis to Cigarette Smoke

Condensate.

Front. Microbiol. 12:744800.

doi: 10.3389/fmicb.2021.744800

\section{Danicke Willemse ${ }^{1 \dagger}$, Chivonne Moodley ${ }^{1,2}$, Smriti Mehra ${ }^{1,2}$ and Deepak Kaushal ${ }^{1 *}$ \\ ${ }^{1}$ Southwest National Primate Research Center, Texas Biomedical Research Institute, San Antonio, TX, United States, \\ 2 Tulane National Primate Research Center, Tulane University Health Sciences Center, Covington, LA, United States}

Smoking is known to be an added risk factor for tuberculosis (TB), with nearly a quarter of the TB cases attributed to cigarette smokers in the 22 countries with the highest TB burden. Many studies have indicated a link between risk of active TB and cigarette smoke. Smoking is also known to significantly decrease TB cure and treatment completion rate and increase mortality rates. Cigarette smoke contains thousands of volatile compounds including carcinogens, toxins, reactive solids, and oxidants in both particulate and gaseous phase. Yet, to date, limited studies have analyzed the impact of cigarette smoke components on Mycobacterium tuberculosis (Mtb), the causative agent of TB. Here we report the impact of cigarette smoke condensate (CSC) on survival, mutation frequency, and gene expression of Mtb in vitro. We show that exposure of virulent $M t b$ to cigarette smoke increases the mutation frequency of the pathogen and strongly induces the expression of the regulon controlled by $\mathrm{SigH}-\mathrm{a}$ global transcriptional regulator of oxidative stress. SigH has previously been shown to be required for $M$ tb to respond to oxidative stress, survival, and granuloma formation in vivo. A high-SigH expression phenotype is known to be associated with greater virulence of Mtb. In patients with pulmonary TB who smoke, these changes may therefore play an important, yet unexplored, role in the treatment efficacy by potentially enhancing the virulence of tubercle bacilli.

Keywords: smoking, cigarette smoke, tuberculosis, sigH, mycobacterium

\section{INTRODUCTION}

Cigarette smoking is practiced by an estimated $20.7 \%$ of the world's population, $80 \%$ of which belong to low- and middle-income countries. Smoking is considered an added risk factor for tuberculosis (TB), with nearly a quarter of the TB cases attributed to cigarette smokers in the 22 countries with the highest TB burden (WHO, 2019). Many studies have indicated a link between risk of active TB and cigarette smoke, with some predicting as much as a fivefold increase in the risk of active TB in smokers compared to non-smokers (Yu et al., 1988; Jha et al., 2008; Lin et al., 2009; Rao et al., 2012, 2017; Ozturk et al., 2014; Smith et al., 2015; Bronner Murrison et al., 2016). Smoking also significantly decreases $\mathrm{TB}$ cure and treatment completion and increases mortality rates (Chiang et al., 2012; Bonacci et al., 2013).

Whole cigarette smoke contains thousands of volatile compounds including carcinogens, toxins, reactive solids, and oxidants in both gaseous and particulate phase. Generation of whole 
cigarette smoke under laboratory conditions (containing both the soluble and insoluble fractions of cigarettes smoke that would be inhaled into the lungs of a smoker) is challenging. Two forms of cigarette smoke, cigarette smoke extract (CSE) and cigarette smoke condensate (CSC), are therefore routinely used for investigating the effect of cigarette smoke components in vitro and in situ. CSE is obtained by dissolving the water-soluble gas and particulate phase, generated from puffing a lit cigarette, in a phosphate-buffered saline solution. CSC consists of the waterinsoluble fraction and is generated by passing the cigarette smoke through a filter pad and eluting the particles collected on the filter in a solvent. The compositions of CSE and CSC differ, with nicotine for instance making up $55.8 \%$ of CSC but only $8.98 \%$ of CSE (Mutepe et al., 2013). This is important to note when using either for investigating the effect of cigarette smoke. CSC has been used in many research studies to study the effect of cigarette smoke (Baboni et al., 2010; Mutepe et al., 2013; Cockeran et al., 2014; Semlali et al., 2014; Cholo et al., 2020).

Some of the compounds of cigarette smoke are pro- and others anti-inflammatory (Borgerding and Klus, 2005; Stampfli and Anderson, 2009; Kim et al., 2018). It increases the permeability of the epithelium, impairs mucociliary clearance, alters metabolism of cells, and induces oxidative and nitrosative damage to cell membranes and DNA-thereby ultimately causing apoptosis. Although smoking increases the production of pro-inflammatory cells, it compromises their ability to phagocytose and kill bacteria, thereby increasing bacterial burden (Stampfli and Anderson, 2009; Feng et al., 2011; Shaler et al., 2013; Agarwal et al., 2014; O'Leary et al., 2014; Aryanpur et al., 2016a,b; Bai et al., 2017). Smoking also causes genomic DNA mutations that are associated with cancers (Alexandrov et al., 2020).

The respiratory tract microbiota differs significantly between smokers and non-smokers (Charlson et al., 2010; Yu et al., 2017). Although many studies have investigated the effect of cigarette smoke on the host cells and responses, limited studies have been done to investigate the effect of cigarette smoke on human pathogens that commonly infect the respiratory tract. Cigarette smoke increases oxidative stress and biofilm formation in Pseudomonas aeruginosa (Chien et al., 2020), Staphylococcus aureus (Kulkarni et al., 2012; Hwang J. H. et al., 2016), Streptococcus mutants (Baboni et al., 2010), and the sino-nasal microbiota of smokers (Goldstein-Daruech et al., 2011). Increased cell adhesion, favoring persistent colonization, is observed in S. aureus and methicillin-resistant S. aureus (MRSA) (Kulkarni et al., 2012; Crotty Alexander et al., 2015; McEachern et al., 2015; Hwang J. H. et al., 2016). An upregulation of virulence genes and concomitant increased virulence is observed in P. aeruginosa and S. aureus (McEachern et al., 2015; Hwang J. H. et al., 2016; Kulkarni et al., 2016; Chien et al., 2020). Expression of virulence and adhesion factors are, however, not upregulated in Streptococcus pneumoniae (Manna et al., 2018), while biofilm formation is (Mutepe et al., 2013). Mycobacterium tuberculosis (Mtb) biofilm formation is also increased upon exposure to CSC (Cholo et al., 2020). Detoxifying enzymes, efflux pumps, and osmoregulator transporters, which can provide a direct defense against the cigarette smoke, are upregulated, while fatty and lipoteichoic acid synthesis is downregulated in S. pneumoniae
(Manna et al., 2018). These different responses could suggest a bacterial specific cigarette smoke response.

It was suggested that the aforementioned changes may be heritable and therefore likely due to genetic modifications brought about by the cigarette smoke exposure. Resistance to antimicrobial agents is for instance observed as a result of cigarette smoke exposure (Miyahara et al., 2011; Crotty Alexander et al., 2015, 2018; Hwang J. H. et al., 2016; Hwang J. Y. et al., 2016; Chien et al., 2020). Although this resistance is linked to changes in the cell wall in MRSA (McEachern et al., 2015), cigarette smoke exposure was directly linked to clinically relevant mutations in drug [rifampicin (RIF) and ciprofloxacin] resistance genes of $P$. aeruginosa (Miyahara et al., 2011). In Salmonella typhimurium, the induction of mutant variants is also observed upon exposure to cigarette smoke components (Claxton et al., 1989; Aufderheide and Gressmann, 2007, 2008). This mutability is smoke concentration, composition, time of exposure, and strain dependent (Mizusaki et al., 1977; Morin et al., 1987; Camoirano et al., 1994; Yim and Hee, 2001; Yim et al., 2002; Aufderheide and Gressmann, 2007, 2008; Roemer et al., 2016; Thorne et al., 2016). It was previously suggested that cigarette smoke should also be considered as a mutagenic substance to $M t b$, the causative agent of TB (McGrath et al., 2014). To our knowledge, the effect of CSC on the transcriptional response of Mtb has, however, not been investigated. In this study, the effects of CSC on the survival of $M t b$, mutation frequency, and gene expression profile in vitro are explored.

\section{MATERIALS AND METHODS}

\section{Bacterial Culture Conditions}

Mtb CDC1551 (BEI: NR-13649) was cultured in 7H9 containing $0.05 \%$ Tween-80 and supplemented with $0.2 \%$ glycerol and $10 \%$ oleic acid, albumin, dextrose, catalase (OADC) (Middlebrook) (subsequently referred to as $7 \mathrm{H} 9$ OADC). For exposure to CSC, 7H9 supplemented with $0.2 \%$ glycerol and dextrose (20 g/l) containing $0.05 \%$ Tween-80 (referred to as $7 \mathrm{H} 9$ dextrose) was used. CSC (Murty Pharmaceuticals, Lexington, KY, United States) was diluted fivefold in dimethyl sulfoxide (DMSO) to prepare working stock of $8 \mathrm{mg} / \mathrm{ml}$ which was added to $7 \mathrm{H} 9$ dextrose where indicated. Bacteria were also cultured on $7 \mathrm{H} 11$ agar (Difco) supplemented with $0.5 \%$ glycerol and $10 \%$ OADC (prepared in the laboratory: $0.06 \%$ oleic acid, $5 \%$ albumin, $2 \%$ dextrose, $0.004 \%$ catalase, $0.85 \%$ sodium chloride, and filter sterilized) (subsequently referred to as $7 \mathrm{H} 11$ agar) for colony-forming unit (CFU) enumeration. A RIF stock solution of $10 \mathrm{mg} / \mathrm{ml}$ was prepared in $10 \%$ DMSO $90 \%$ water solution and used where necessary at $2 \mu \mathrm{g} / \mathrm{ml}$ final concentration in 7H11 agar.

\section{MIC Determination}

A serial twofold dilution series of CSC working solution $(8 \mathrm{mg} / \mathrm{ml}$ in DMSO), DMSO, and 7H9 dextrose was prepared in 7H9 dextrose in a 96-well plate. $M t b$ cultures at day 4 of growth were diluted to optical density (OD) of 0.002 and equal volumes added to these serial dilutions (total $100 \mu \mathrm{l}$ ). After 3 weeks of 
growth at $37^{\circ} \mathrm{C}$, resazurin $(30 \mu \mathrm{l}$ of a $0.02 \%$ stock $)$ was added to each well and color development was allowed overnight. Pink wells indicated growth and blue, no growth. DMSO wells served as control for the effect of the CSC diluent on the growth of $M t b$ while the $7 \mathrm{H} 9$ dextrose wells served as positive $M t b$ growth controls. Three independent replicate experiments were done.

\section{Cigarette Smoke Condensate Exposure Survival Assays}

Starter cultures were cultured in 7H9 OADC for 6 days, subcultured to OD 0.05, and allowed to grow for 4 days. Bacteria were collected, washed twice in $7 \mathrm{H} 9$ dextrose to remove catalase, resuspended in 7H9 dextrose, and sonicated to remove clumps. After filtering through a 0.2 -micron cell strainer (Falcon) to remove clumps, the cultures were diluted to an OD of 0.2. For survival assays, these cultures were split into 10 -ml cultures and exposed to 25,50 , or $75 \mu \mathrm{g} / \mathrm{ml} \mathrm{CSC}$ or DMSO only (unexposed) for 3, 6, 24, and $48 \mathrm{~h}$. Dilution series were prepared at each time point in phosphate-buffered saline (PBS) ( $\mathrm{pH} 7.4$ ) containing $0.5 \%$ Tween- 80 and proper dilutions plated on $7 \mathrm{H} 11$ agar. CFUs were enumerated after 3-4 weeks. The percentage survival was calculated by dividing the CFU/mL of CSC exposed cultures with that of the DMSO-exposed (unexposed) cultures, which was set as $100 \%$ survival.

\section{Mycobacterium tuberculosis Mutation Frequency Determination}

Rifampicin resistance is generally acquired by mutations in the $r p o B$ gene of $M t b$ (Hirano et al., 1999). The acquisition of these mutations and subsequent ability of the bacteria to grow in the presence of RIF have been used in many studies to study the mutation frequency and rate in Mtb (McGrath et al., 2014). These assays were adapted for mutation frequency determination after exposure to CSC. Exposure to the diluent of CSC, DMSO, was taken as the mutation rate without exposure, to exclude any influence of the diluent. Preparation of cultures was done as for the CSC survival assays. Cultures were split into $30-\mathrm{ml}$ cultures and exposed to $50 \mu \mathrm{g} / \mathrm{ml}$ CSC or equal volume of DMSO (unexposed) for 3 and $24 \mathrm{~h}$. Dilution series of two separate cultures were prepared in PBS containing 0.5\% Tween-80 and proper dilutions plated on $7 \mathrm{H} 11$ agar. Undiluted cultures $(10 \mathrm{ml}$, $1 \mathrm{ml}$, and $100 \mu \mathrm{l}$ ) were also plated on $7 \mathrm{H} 11$ agar containing $2 \mu \mathrm{g} / \mathrm{ml}$ RIF. CFU enumeration was done after 4 weeks to exclude the presence of satellite colonies. The mutation frequency in the presence of CSC was calculated by using the average CFU in the two cultures exposed to CSC plated on 7H11 agar RIF (representing the RIF resistant mutants) and dividing it by the average CFU in the two cultures exposed to CSC plated on 7H11 agar (total bacterial count). The mutation frequency was calculated in the same way for the DMSO (unexposed) cultures. Three independent exposure experiments were done.

\section{RNA Extraction}

Cultures $(30 \mathrm{ml})$, prepared as for CSC mutation frequency analysis, were collected by centrifugation at 4,000 rpm, resuspended in $1 \mathrm{ml}$ RNAProBlue solution (MP Biomedicals,
Santa Ana, CA, United States), transferred to a 2-ml tube containing $0.2-\mathrm{mm}$ matrix $\mathrm{B}$ beads (MP Biomedicals) and frozen at $-80^{\circ} \mathrm{C}$ until use. After defrosting, bacteria were lysed by bead beating at 3,800 rpm for 3 cycles of $30 \mathrm{~s}$ each, using a BioSpec Mini-Beadbeater-24 and cellular debris removed by centrifugation at $15,000 \times g$ for $15 \mathrm{~min}$. Chloroform $(300 \mu \mathrm{l})$ was added and the reaction vortexed for $10 \mathrm{~s}$. The NucleoSpin RNA kit (Macherey-Nagel, Düren, Germany) was used for RNA extraction according to the manufacturer's instructions. Even though an on-column rDNase treatment was done, the RNA was also treated with Turbo DNase from the TURBO DNA-free Kit (Ambion, Foster City, CA, United States) kit according to the manufacturer's instructions. Following inactivation of the DNase using inactivation reagent (Ambion), the RNA Clean \& Concentrator Kit (Zymo) was used to get rid of the DNase buffer and RNA was eluted in RNase-free water. Retreatment with Turbo DNase and cleanup using the RNA clean \& concentrator kit were done, if DNA was still present. The concentration of RNA was determined using the Qubit RNA BR Assay Kit (Thermo Fisher Scientific, Waltham, MA, United States), and DNA contamination was assessed using the Qubit $1 \times$ dsDNA HS Assay Kit (Thermo Fisher Scientific) on a Qubit Flex Fluorometer (Thermo Fisher Scientific). RNA quality was assessed using the 4200 TapeStation System by the Texas Biomedical Research Institute Molecular Core facility.

\section{RNA-Sequencing}

The Zymo-Seq RiboFree Total RNA Library Kit was used for library preparation according to the manufacturer's instructions. RNA (500 ng) was used and ribosomal depletion done for $30 \mathrm{~min}$, followed by 14 cycles of PCR. RNA-seq was done using the Illumina NextSeq 500 V2.5 kit according to the manufacturer's instructions on the NextSeq 500 machine by the UTHSCSA Genome Sequencing Facility. Sequencing reads were subjected to secondary data analysis using the Partek Flow (Partek Inc., Chesterfield, MO, United States) pipeline. In short, reads were filtered based on quality of Phred 30 with minimum read lengths of 25 nucleotides and aligned to the $M t b$ CDC1551 reference genome sequence (European Nucleotide Archive ASM858v1) using the RNA-seq aligner STAR v2.5.3a. Post-alignment quality assessment, transcript abundance estimation according to ASM858v1 transcriptome annotation by expectation-maximization algorithm, and sample read count normalization using Transcripts Per Kilobase Million (TPM) were done.

\section{Differential Gene Expression Analysis}

Read count data (not normalized) were uploaded into the iDEP91 online RNA-seq analysis software (Ge et al., 2018). The minimal counts per million (CPM) were kept at default of 0.5 in at least one library. Count data were transformed for clustering and principal component analysis using EdgeR: log2 $(\mathrm{CPM}+\mathrm{c})$ and pseudocount (c) of 4. Gene IDs were not converted to Ensembl. Where multiple transcripts were present, full stops were replaced with underscores in the read count files to enable recognition of the transcripts as distinct. Missing-value imputation was done 
TABLE 1 | Gene-specific primers used for RT-qPCR analysis.

\begin{tabular}{ll}
\hline Gene primer & Sequence $\left(5^{\prime}-3^{\prime}\right)$ \\
\hline SigAFor & TGCAGTCGGTGCTGGACAC \\
SigARev & CGCGCAGGACCTGTGAGCGG \\
MT3320For & GTCCAACGCCGAGCATTCCT \\
MT3320Rev & CCTGCAGCGCCTCTITGATCT \\
MT1608For & AGGAGGAGATCGGTGCAGGT \\
MT1608Rev & ACCGAGGACCCGCAAATCAC \\
MT1259For & GCTACACCGCATCACCACCA \\
MT1259Rev & GTGCGTCGTGGTAGATCTGCT \\
MT0997For & ACGTCTCGCTGAAGGTGGTC \\
MT0997Rev & TGCACCCCGGTCACTTGG \\
\hline
\end{tabular}

using the gene median. Principal component analysis was done. Differentially expressed genes were identified using the DESeq2 option on the iDEP91 software, with an FDR of 0.1 and minimum fold change of 2.0. Time was considered as a factor. Exposure to CSC was considered the main factor, reference DMSO used when comparing CSC vs. DMSO, and batch effect considered. The function of genes differentially expressed in the presence of CSC was determined by literature search on Google Scholar and the Mycobrowser website ${ }^{1}$. Raw and analyzed data can be accessed from GEO via the accession number GSE172041.

\section{Confirmation of Gene Expression by RT-qPCR}

Some genes, which were differentially regulated by exposure to CSC according to RNA-seq data, were selected for confirmation of gene expression levels by RT-qPCR. RNA (500 ng) was reverse transcribed using random primers and the High-Capacity cDNA Reverse Transcription Kit (Thermo Fisher Scientific) according to the manufacturer's instructions in a Veriti 96well thermal cycler (Thermo Fisher Scientific). No reverse transcriptase controls were done to confirm the absence of DNA in the RNA samples. PCR was done using $0.5-\mu \mathrm{M}$ primers (Table 1) and the Applied Biosystems PowerUp SYBR Green Master Mix kit (Thermo Fisher Scientific) according to the manufacturer's instructions. cDNA was diluted 100fold before use in the PCR reactions. PCR conditions used were $50^{\circ} \mathrm{C}$ for $2 \mathrm{~min}, 95^{\circ} \mathrm{C}$ for $2 \mathrm{~min}$, followed by 40 cycles of $95^{\circ} \mathrm{C}$ for $15 \mathrm{~s}, 60^{\circ} \mathrm{C}$ for $18 \mathrm{~s}$, and $72^{\circ} \mathrm{C}$ for $30 \mathrm{~s}$. Melt curve analysis was done $\left(95^{\circ} \mathrm{C}\right.$ for $15 \mathrm{~s}, 60^{\circ} \mathrm{C}$ for $1 \mathrm{~min}$, and $95^{\circ} \mathrm{C}$ for $15 \mathrm{~s}$ ) to confirm the presence of only one PCR product and the absence of primer dimers. The $\Delta \Delta \mathrm{Ct}$ method was used and normalization done with $\operatorname{sig} A$ as a housekeeping gene.

\section{Statistical Calculations}

All graphs were plotted using GraphPad Prism 8.02 or iDEP91 software available online, as indicated above (Ge et al., 2018). Multiple $t$-tests were done, without assuming equal deviation or correction for multiple comparisons, and $p \leq 0.05$ was considered statistically significant.

${ }^{1}$ https://mycobrowser.epfl.ch/

\section{RESULTS}

\section{Effect of Cigarette Smoke Condensate on Mycobacterium tuberculosis Growth and Survival}

The effect of nicotine, one of the cigarette smoke components, on non-tuberculous mycobacteria and CSC on $M t b$ was previously investigated and shown to have no effect on the growth in vitro (Greenstein et al., 2011; Cholo et al., 2020). Since the effect of CSC was previously investigated in H37Rv strain and in 7H9 OADC media (containing catalase which mops up reactive oxygen species), we determined the effect of CSC on the growth and survival of the CDC1551 strain in the absence of catalase to determine the concentrations of CSC to be used in this study. Firstly, we investigated the concentration at which CSC inhibits $M t b$ 's growth by doing MIC assays. The growth of Mtb was present in all wells containing only $7 \mathrm{H} 9$ dextrose. No growth was observed at a CSC concentration of $125 \mu \mathrm{g} / \mathrm{ml}$, while growth was still present at $62.5 \mu \mathrm{g} / \mathrm{ml}$, making the MIC between 62.5 and 125 $\mu \mathrm{g} / \mathrm{ml}$. This was as a result of CSC and not the diluent, DMSO, since growth was observed up to $3.125 \% \mathrm{DMSO}$ and only $0.78 \%$ DMSO was present in the $62.5-\mu \mathrm{g} / \mathrm{ml}$ CSC well. Based on the MIC, $M t b$ was exposed to 25,50 , and $75 \mu \mathrm{g} / \mathrm{ml} \mathrm{CSC} \mathrm{or} \mathrm{DMSO} \mathrm{(0}$ $\mu \mathrm{g} / \mathrm{ml}$ ) for $3,6,24$, and $48 \mathrm{~h}$ in $7 \mathrm{H} 9$ dextrose media. Survival was assessed by CFU enumeration and relative to DMSO exposure, which was set as $100 \%$ survival. No significant difference in bacterial survival upon exposure to CSC was observed at the different CSC concentrations or time points tested (Figure 1A).

\section{Effect of Cigarette Smoke Condensate on Mutation Frequency of Mycobacterium tuberculosis}

Since CSC contains a whole array of toxic compounds (Borgerding and Klus, 2005; Kim et al., 2018) and was shown to be mutagenic in other bacteria (Claxton et al., 1989; Aufderheide and Gressmann, 2007, 2008; Miyahara et al., 2011), the effect of $M t b$ on mutation frequency was investigated. Growth on RIF was considered as genotypic development of RIF resistance. The frequency of RIF mutations in the presence of CSC $(50 \mu \mathrm{g} / \mathrm{ml})$ was compared to the frequency of RIF mutations in the diluent of CSC, DMSO. The mutation frequency in the presence of CSC was significantly (2.32-fold) higher than in DMSO (Figure 1B).

\section{Transcriptional Response to Cigarette Smoke Condensate}

RNA was extracted from $M t b$ cultures exposed to $50 \mu \mathrm{g} / \mathrm{ml}$ CSC and DMSO for 3 and $24 \mathrm{~h}$. To investigate the transcriptional response of $M t b$ to CSC, RNA-sequencing was done and reads mapped to the CDC1551 reference genome. Comparable total reads per million counts were observed for all the samples (Figure 2A). PCA showed that time was the biggest factor in differential gene expression (Figure 2B). This is likely due to multiple factors including the composition and concentration of CSC that likely changed as a result of the volatile nature of CSC. Bacterial growth was also observed previously between 

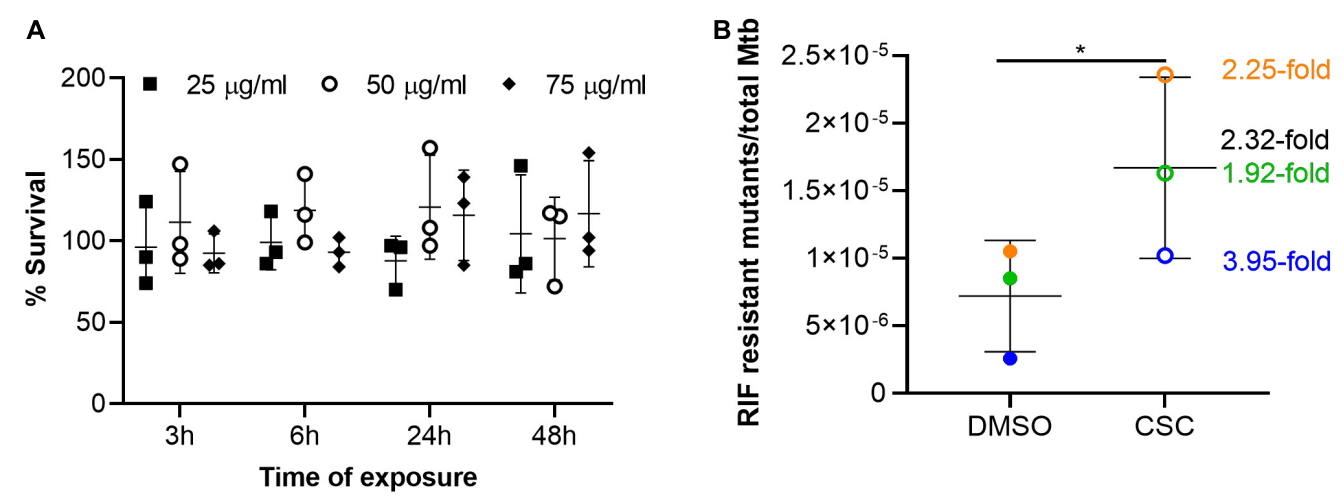

FIGURE 1 | Survival and mutation frequency in Mtb exposed to CSC. (A) Survival of Mtb upon exposure to 25, 50, and 75 $\mu \mathrm{g} / \mathrm{ml}$ CSC for 3, 6 , 24 , and 48 h relative to survival upon exposure to the diluent, DMSO, which was set as $100 \%$. Multiple $t$-tests were done $(n=3)$, without assuming standard deviation and without correction for multiple comparisons. No significant differences were observed. (B) Frequency of RIF-resistant mutants, determined by CFU on $7 \mathrm{H} 11$ agar RIF (2 $\mu \mathrm{g} / \mathrm{ml})$, compared to bacterial count in the culture, determined by plating dilution series on $7 \mathrm{H} 11$ agar. Three independent experiments ( $n=3$ ) were done and are indicated in different colors. The fold difference in mutation frequency between CSC and DMSO is indicated in the corresponding color with black indicating the mean fold change. The error bars indicate the mean and standard deviation. A paired, two-tailed $t$-test indicated significant increase in mutation frequency upon exposure to $\operatorname{CSC}(p=0.034)$. ${ }^{\star} p<0.05$.

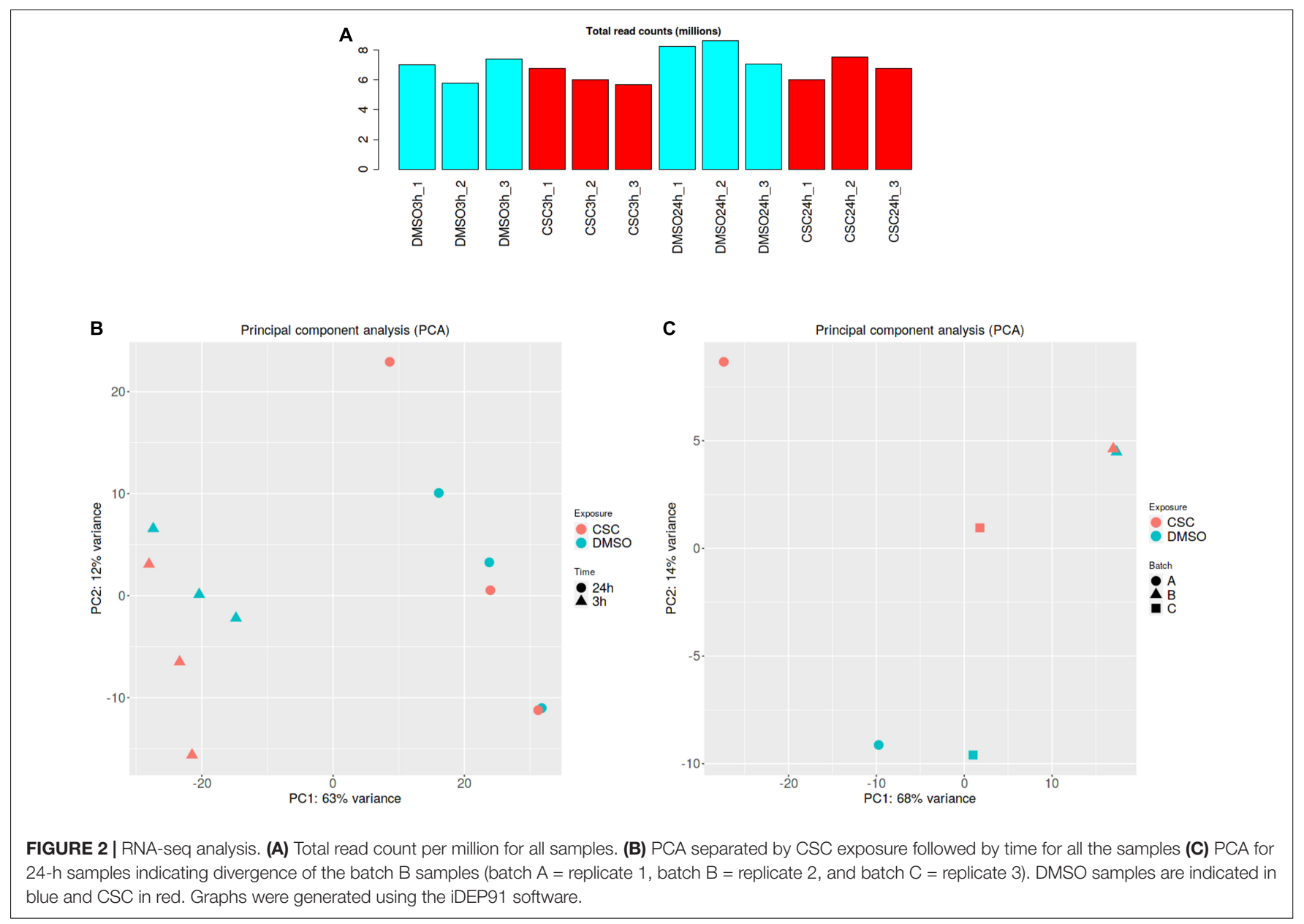

the 3- and 24-h time points, contributing to the different bacterial state and transcription at the two time points. Larger variations may also mask some smaller differences in the effect of CSC during the analysis. A separate analysis of the 3- and 24-h data was therefore done. Of the 4,007 genes for which expression was assessed at $3 \mathrm{~h}$ of exposure, 3,968 genes passed 
CPM filtering. Clustering of CSC-exposed and DMSO-exposed replicates/batches was observed. For the 24-h-exposed samples, PCA indicated clustering for replicates 1 and 3 (batches $\mathrm{A}$ and C) while replicate 2 (batch B) did not cluster as expected (Figure 2C). Replicate 2 samples were therefore excluded from all subsequent analyses for the 24-h samples. Of the 4,007 genes identified in the remaining four 24-h samples, 3,939 genes passed the CPM filter.

Following exposure to CSC for $3 \mathrm{~h}, 59$ genes were upregulated more than twofold while only one was downregulated (Table 2). Genes upregulated upon exposure to CSC at $3 \mathrm{~h}$ included those encoding sigma factors [MT3320 (sigH), MT1259 (sigE), MT2783 (sigB), and MT3319], ESAT-6-associated prolineproline-glutamate (PPE) proteins [MT1068 (PPE15) and MT1850 (PPE29)], and other virulence and reactivationassociated genes [MT1608 (mmpl6) and (MT0148)]. Multiple genes which are regulated by SigH were upregulated, including genes encoding oxidoreductases (MT3569 and MT0083) and thioredoxin reductases [MT0838 (thiX), MT1517 (trxB), MT4032 (trxB2), and MT4033 (trxC)]. Genes encoding proteins involved in stress response such as MT0365 (dnaK), MT0366 (grpE), MT0397 ( $c l p B)$, and MT3438) and genes previously shown to be induced by DNA damage [MT2881 and MT3142 (dinP)] were upregulated.

Since heavy metals are a known component of cigarette smoke (Borgerding and Klus, 2005), it was not surprising that the copper-responsive regulon and other genes encoding copper responsive/export systems [MT0995 (csoR), MT0996, MT0997 (ctpV), MT0998, MT0196 (mymT), MT0869, MT0873, and MT3039] as well as molybdenum [MT3301 (moeZ)] and cadmium [MT2719 (cadI)] responsive genes were upregulated by CSC. At $24 \mathrm{~h}$ of exposure to CSC, only seven genes were upregulated and three downregulated. Only five genes, which were upregulated at $3 \mathrm{~h}$ of CSC exposure, remained upregulated at $24 \mathrm{~h}$ including a methyltransferase (MT0586), MT1608 (mmpL6), a probable dehydrogenase MT3140, possible dioxygenase (MT3250), and TetR/MarR regulator (MT3249) encoding genes. Two genes encoding MarR family transcriptional regulators and bacterioferritin [MT0706_1 and MT3949 (brfB)] were upregulated at $24 \mathrm{~h}$, but not $3 \mathrm{~h}$ of CSC exposure. RNA-seq results were confirmed by RT-qPCR for selected genes (Figure 3).

\section{DISCUSSION}

The significant link between cigarette smoking and TB disease has seen research into the effect of cigarette smoke on host factors. Although an effect of cigarette smoke on the causative agent, $M t b$, has been suggested (McGrath et al., 2014) and this effect has been investigated on other respiratory bacteria, no studies have, to our knowledge, investigated the effect of CSC on the transcriptional profile or mutagenesis of $M t b$.

Cigarette smoke condensate inhibited $M t b$ 's growth at a concentration between 62.5 and $125 \mu \mathrm{g} / \mathrm{ml}$ in in vitro cultures. $M t b$ 's survival upon exposure to CSC was not significantly affected, although slightly lower CFUs were observed upon CSC exposure compared to DMSO (Figure 1A). CSC previously did not affect the growth of $M t b \mathrm{H} 37 \mathrm{Rv}$ in planktonic 7H9 OADC cultures in 96-well plates (Cholo et al., 2020). One of the main components of cigarette smoke, nicotine, did not affect growth of non-tuberculous mycobacteria in culture (Greenstein et al., 2011) but did promote the growth of $M t b$ in epithelial cells (Miramontes et al., 2021). An initial bacteriostatic effect of CSC, within the first $24 \mathrm{~h}$, was observed during survival assays, although doubling of bacteria occurred after $48 \mathrm{~h}$. This is likely due to the dissipation, degradation, and/or chemical changes of the volatile compounds within CSC within the 24-h period. Additionally, interaction of CSE with plastic containers and degradation and/or evaporation of CSE was previously shown to influence the bioavailability of the cigarette smoke components in cell culture experiments (Bourgeois et al., 2016). The volatile nature of CSC is therefore a limiting factor when attempting to explore the effects of more long-term CSC exposure on $M t b$. It would be interesting to investigate the effects of cigarette smoking on $M t b$ load and virulence factors in animal models such as a macaque model, which closely mimics the immune response in humans.

A 2.32-fold higher mutation frequency was observed after $24 \mathrm{~h}$ of exposure to CSC compared to exposure to DMSO (Figure 1B). Strain background, CSC concentration, composition, and time of exposure likely influenced the mutability of $M t b$ upon exposure to cigarette smoke (Mizusaki et al., 1977; Morin et al., 1987; Camoirano et al., 1994; Yim and Hee, 2001; Yim et al., 2002; Aufderheide and Gressmann, 2007, 2008; Bourgeois et al., 2016; Roemer et al., 2016; Thorne et al., 2016). It was also shown that the effect of CSE on bacteria was highly dependent on the bacterial-load-to-CSE ratio (Bourgeois et al., 2016). The effect of the ratio of $M t b$ to CSC concentration, bacterial growth phase, and strain background on the mutability of CSC should therefore be investigated in future studies.

Initially, the intention was to investigate the mutation rate and not just frequency. Preliminary experiments, however, indicated a negative mutation rate (data not shown), likely as a result of bacterial growth and death rate, since these factors had a significant effect on mutation rate calculations in previous studies (Frenoy and Bonhoeffer, 2018). A slight drop in the Mtb CFU was observed upon exposure to CSC, although this death did not cause significant percentage survival differences compared to DMSO controls (Figure 1A). Traditionally Luria-Delbrück assays, which use extremely low bacterial counts (thereby allowing exclusion of preexisting mutants from the cultures) and culturing for a prolonged time, are done to assess the mutation frequency and rate. This technique was, however, not usable due to the extremely volatile nature of CSC and inability to culture a low bacterial burden culture for an extended time. Another study has since also used cultures at mid-log growth for mutation rate analysis (Naz et al., 2021). Due to the volatile nature of CSC, the compounds to which $M t b$ were exposed likely also changed during the exposure time, thereby making the exposure conditions variable and mutation rate assessment challenging, if not impossible. Due to its slow growth, the mutation rate of $M t b$ CDC1551 is extremely low.

Mutation rate is also dependent on the drug used for mutation assessment (Ford et al., 2013). The use of phenotypic 
TABLE 2 | Genes differentially expressed in Mtb after 3 and 24 h of CSC exposure.

\begin{tabular}{|c|c|c|c|c|c|c|c|c|}
\hline \multirow[b]{2}{*}{$\begin{array}{l}\text { Gene ID } \\
\text { CDC1551 }\end{array}$} & \multirow[b]{2}{*}{$\begin{array}{l}\text { Gene ID } \\
\text { H37Rv }\end{array}$} & \multirow[b]{2}{*}{$\begin{array}{l}\text { Gene } \\
\text { name }\end{array}$} & \multirow[b]{2}{*}{ Function } & \multirow[b]{2}{*}{ References } & \multicolumn{2}{|c|}{ Regulation at $3 \mathrm{~h}$} & \multicolumn{2}{|c|}{ Regulation at $24 \mathrm{~h}$} \\
\hline & & & & & $\begin{array}{l}\text { log2Fold } \\
\text { Change }\end{array}$ & $p$-value & $\begin{array}{l}\text { log2Fold } \\
\text { Change }\end{array}$ & $p$-value \\
\hline \multicolumn{9}{|c|}{ Upregulated genes: } \\
\hline MT0083 & Rv0077c & ethA2 & Putative oxidoreductase protein & Wohlkonig et al., 2017 & 4.23 & $9.31 E-45$ & & \\
\hline MT0148 & Rv0140 & & Mtb reactivation-associated proteins & Wayne and Hayes, 1996 & 2.43 & $1.12 \mathrm{E}-02$ & & \\
\hline МT0196 & MT0196 & MymT & Copper-binding metallothionein & Gold et al., 2008 & 2.38 & 4.49E-30 & & \\
\hline MT0365* & Rv0350 & dnak & $\begin{array}{l}\text { Important for stress-responsive } \\
\text { regulator heat shock protein } \mathrm{R}(\mathrm{HspR}) \\
\text { function }\end{array}$ & $\begin{array}{l}\text { Bandyopadhyay et al., } \\
\qquad 2012\end{array}$ & 1.13 & $5.80 \mathrm{E}-06$ & & \\
\hline MT0366* & Rv0351 & $\operatorname{grp} E$ & Heat shock stress-responsive element & $\begin{array}{l}\text { Bandyopadhyay et al., } \\
\qquad 2012\end{array}$ & 1.12 & $1.08 \mathrm{E}-05$ & & \\
\hline MT0397* & Rv0384c & $c / p B$ & $\begin{array}{l}\text { Essential stress regulator of } M \text { tb and } \\
\text { endows survival advantage to dormant } \\
\text { bacilli }\end{array}$ & Tripathi et al., 2020 & 1.33 & $1.90 \mathrm{E}-07$ & & \\
\hline MT0586 & Rv0560c & & Methyltransferase & Chen et al., 2019 & 4.52 & $\begin{array}{l}2.77 \mathrm{E}- \\
202\end{array}$ & 3.53 & 1.96E-29 \\
\hline MT0706.1 & Rv0678 & & MarR family of transcriptional regulator & $\begin{array}{l}\text { Radhakrishnan et al., } \\
\qquad 2014\end{array}$ & - & - & 1.33 & 2.01E-03 \\
\hline МТ0838 & Rv0816c & thix & Putative thioredoxin & Rahlwes et al., 2020 & 1.54 & $1.54 \mathrm{E}-05$ & & \\
\hline MT0869 & Rv0846c & & Putative multicopper oxidase & $\begin{array}{l}\text { Rowland and Niederweis, } \\
\qquad 2012\end{array}$ & 1.84 & $4.40 E-47$ & & \\
\hline MT0870 & Rv0847 & IpqS & Probable lipoproteins & $\begin{array}{l}\text { Sutcliffe and Harrington, } \\
2004\end{array}$ & 1.49 & $5.55 E-29$ & & \\
\hline MT0873 & Rv0850 & & $\begin{array}{l}\text { Putative transposase, } \\
\text { copper-responsive }\end{array}$ & Festa et al., 2011 & 1.05 & $2.04 \mathrm{E}-05$ & & \\
\hline МT0995 & Rv0967 & $\operatorname{csoR}$ & $\begin{array}{l}\text { Copper-dependent regulation of the } \\
\text { copper responsive operon }\end{array}$ & Liu et al., 2007 & 2.39 & 2.63E-03 & & \\
\hline МT0996 & Rv0968 & & $\begin{array}{l}\text { Hypothetical protein, part of the copper } \\
\text { responsive operon }\end{array}$ & Festa et al., 2011 & 2.32 & 1.38E-03 & & \\
\hline МT0997 & Rv0969 & ctpV & $\begin{array}{l}\text { Putative copper exporter, required for } \\
\text { full virulence in } M t b\end{array}$ & Ward et al., 2010 & 2.31 & $9.52 \mathrm{E}-04$ & & \\
\hline МТ0998 & Rv0970 & & $\begin{array}{l}\text { Part of cos operon, responsive to } \\
\text { copper }\end{array}$ & Liu et al., 2007 & 2.44 & 5.30E-04 & & \\
\hline MT1020* & Rv0991c & & Redox-regulated molecular chaperone & Becker et al., 2020 & 1.65 & $2.40 \mathrm{E}-08$ & & \\
\hline MT1068 & Rv1039c & PPE15 & $\begin{array}{l}\text { Duplicated from ESAT-6 (esx) gene } \\
\text { cluster region } 5\end{array}$ & $\begin{array}{l}\text { Gey van Pittius et al., } \\
2006\end{array}$ & 1.71 & $1.21 \mathrm{E}-03$ & & \\
\hline MT1259 & Rv1221 & SigE & ECF subfamily sigma subunit E & Manganelli et al., 2001 & 1.81 & 3.99E-03 & & \\
\hline MT1376. $1^{\star}$ & Rv1335 & CysO & $\begin{array}{l}\text { Part of the cysteine biosynthesis } \\
\text { pathway }\end{array}$ & Agren et al., 2008 & 1.13 & $1.17 \mathrm{E}-04$ & & \\
\hline MT1517* & Rv1471 & $\operatorname{trx} B$ & $\begin{array}{l}\text { Thioredoxin reductase, disulfide } \\
\text { reductase }\end{array}$ & Akif et al., 2008 & 2.12 & 1.09E-03 & & \\
\hline MT1579* & Rv1528c & & conserved hypothetical & & 2.17 & 3.64E-09 & & \\
\hline MT1608 & Rv1557 & mmpL6 & $\begin{array}{l}\text { Conserved large membrane protein } \\
\text { involved in oxidative stress response }\end{array}$ & Arumugam et al., 2019 & 2.41 & $2.04 \mathrm{E}-35$ & 3.16 & 7.54E-33 \\
\hline MT1711 & Rv1673c & & Conserved hypothetical & & 1.01 & $6.73 \mathrm{E}-03$ & & \\
\hline MT1850 & Rv1801 & PPE29 & $\begin{array}{l}\text { PPE protein-associated with ESAT- } 6 \\
\text { (esx) gene cluster region } 5\end{array}$ & $\begin{array}{l}\text { Gey van Pittius et al., } \\
2006\end{array}$ & 1.52 & $6.54 \mathrm{E}-06$ & & \\
\hline MT1924 & Rv1875 & & $\begin{array}{l}\text { Possible pyridoxine } 5 \text {-phosphate } \\
\text { oxidase }\end{array}$ & Mashalidis et al., 2011 & 1.23 & $1.27 \mathrm{E}-06$ & & \\
\hline MT2066 & Rv2011c & & $\begin{array}{l}\text { Putative MarR family transcriptional } \\
\text { regulator, unknown function }\end{array}$ & Lee et al., 2016 & 2.63 & $3.92 \mathrm{E}-10$ & & \\
\hline MT2067 & Rv2012 & & Conserved hypothetical protein & & 2.38 & $1.25 \mathrm{E}-05$ & & \\
\hline MT2468* & Rv2397c & cysA & $\begin{array}{l}\text { ABC import systems functioning as a } \\
\text { sulfate importer }\end{array}$ & Soni et al., 2020 & 1.01 & 4.03E-05 & & \\
\hline MT2469* & Rv2398c & cysW & Sulfur metabolism & Zeng et al., 2013 & 1.03 & 2.05E-05 & & \\
\hline
\end{tabular}


TABLE 2 | (Continued)

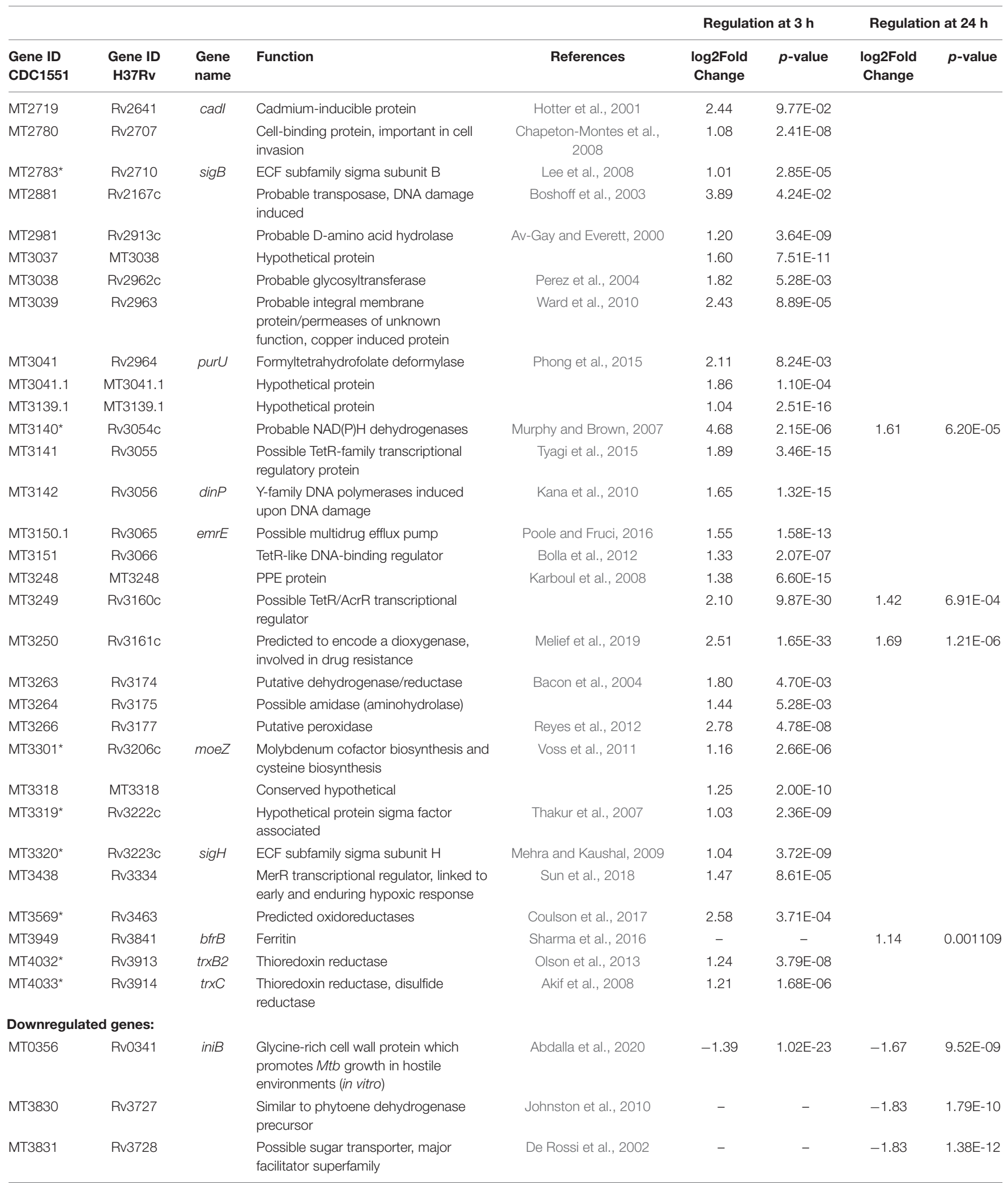

*Indicate genes directly or indirectly regulated by $\mathrm{SigH}$. 


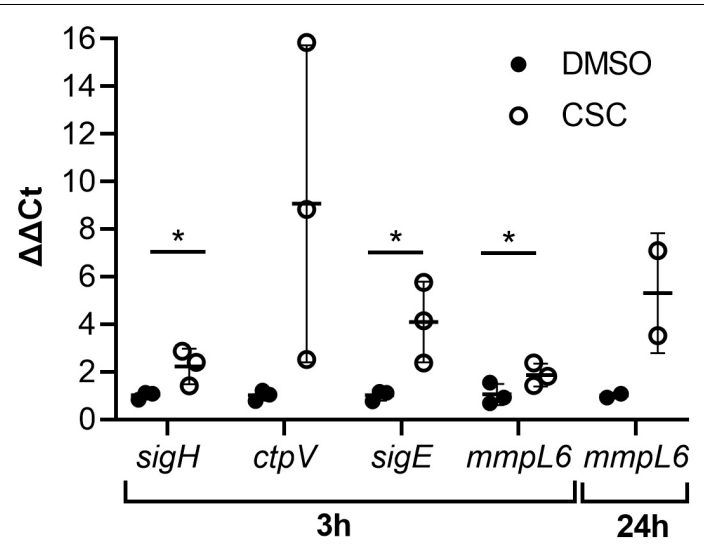

FIGURE 3 | Expression levels of selected genes confirmed by RT-qPCR. The $\Delta \Delta$ Ct values are indicated $(n=3)$ and were calculated relative to the housekeeping gene, sigA. SigA was shown to be consistently expressed in the RNA-seq analysis. Multiple unpaired, one-tailed $t$-tests were done, and $p \leq 0.05$ was considered statistically significant (sigH at $3 \mathrm{~h}$ : DMSO vs. CSC, $p=0.049$; ctpV at $3 \mathrm{~h}$ : DMSO vs. CSC, $p=0.086$; sigE at $3 \mathrm{~h}$ : DMSO vs. CSC, 0.043; mmpL6, 3 h, DMSO vs. CSC, $0.048,24$ h, $p=0.125)$. ${ }^{*} p<0.05$.

RIF resistance as a sole indicator of mutations in $M t b$ and accepting genotypic drug resistance without confirming $r p o B$ mutations in the $M t b$ colonies (which grew on the RIF plates) are therefore major limitations of this study. The increased mutation frequency determined here does, however, suggest that cigarette smoke could have mutagenic effects on $M t b$, which could lead to drug resistance. This is in agreement with what was previously observed for other bacteria (Claxton et al., 1989; Aufderheide and Gressmann, 2007, 2008; Miyahara et al., 2011). It is therefore necessary to assess mutation frequency by wholegenome sequencing, where mutations in multiple genes are detected. Mutations driven by CSC which could lead to Mtb drug resistance may not be related to known mutations in drug resistance genes, but instead to changes in the cell wall or other virulence factors of $M t b$. Using whole-genome sequencing will provide the most complete understanding of the mutagenic properties of CSC on $M t b$. Since the cell wall of $M t b$ is unique (Alderwick et al., 2007) and cigarette smoke has been shown to change the charge on other bacterial surfaces (Crotty Alexander et al., 2015; Hwang J. H. et al., 2016), allowing evasion of the host immune system, it would also be interesting to explore the effect of CSC on the $M t b$ cell wall.

It is also important to remember that CSC contains only the insoluble fractions of cigarette smoke and although it contains many of the chemicals that make up cigarette smoke, limited water-soluble chemicals would be present due to the preparation method (Borgerding and Klus, 2005; Stampfli and Anderson, 2009; Kim et al., 2018). CSC was chosen since it is commercially available and we made use of a single batch during experiments to ensure consistency in its composition. Other methods would require smoking of cigarettes and collection of the water-soluble fractions (CSE), but this would limit the consistency of the composition of the preparation between laboratories and batches and was therefore avoided.
The transcriptional response of $M t b$ to CSC was explored. During the 3-h exposure, the expression of numerous genes was upregulated, while only one was downregulated (Table 2). This likely represents the immediate response to the toxic compounds and oxidative and nitrosative stress generated by CSC. By $24 \mathrm{~h}$, the expression of only five of the 59 genes upregulated at $3 \mathrm{~h}$ remained upregulated. The transcriptional response to CSC therefore seems to be a more immediate and short-lived response.

Interestingly, sigH, a global regulator (Manganelli et al., 2002), and its downstream regulon were induced by CSC (Table 2). $\mathrm{SigH}$ is a global stress response regulator which is induced upon exposure to oxidative and nitrosative stress (Mehra and Kaushal, 2009). Additionally, mmpL6, encoding for conserved large membrane proteins, which is also involved in oxidative stress response (Arumugam et al., 2019), was upregulated at both $3 \mathrm{~h}$ and remained upregulated at $24 \mathrm{~h}$ of CSC exposure (Table 2). Increased oxidative stress was also previously suggested to occur due to exposure to the same CSC (the same preparation used in our study) in $M t b \mathrm{H} 37 \mathrm{Rv}$, since catalase, known to remove oxidative stress, caused significant attenuation of the CSC-mediated changes in biofilm formation in $\mathrm{Mtb}$ (Cholo et al., 2020). The upregulation of oxidative stress response genes is also consistent with the increased oxidative stress observed in other bacteria upon cigarette smoke exposure (Baboni et al., 2010; Goldstein-Daruech et al., 2011; Kulkarni et al., 2012; Hwang J. H. et al., 2016; Chien et al., 2020).

Upregulated genes also included genes known to be directly transcribed under the influence of SigH, e.g., $\operatorname{tr} x \mathrm{~B} 2 / \operatorname{tr} x \mathrm{C}$ operon which encodes for thioredoxin/thioredoxin reductases that play a role in mitigating oxidative stress and downstream sigma factors $\operatorname{sig} E$ and $\operatorname{sig} B$ which further amplify the antioxidative function of sigH. Also induced was the expression of heat shock/chaperonin proteins $d n a K$ and $g r p E$, and $\operatorname{clp} B$, which are critical in resolving protein aggregates that may result during oxidative stress. These genes are coregulated with SigH and SigE (Mehra and Kaushal, 2009). The SigH and SigE regulons are two of the most important regulons allowing response to oxidative stress in $M t b$ (Voskuil et al., 2011). Sixteen genes that are known to be controlled by SigH were upregulated by exposure of $M t b$ to CSC indicating true upregulation of a regulon.

Interestingly, RNA-seq results did not show changes in expression of genes involved in the hypoxia response, e.g., $\operatorname{dos} R$, dosS, or dosT (Mehra et al., 2015). Since SigH is required for pathology in the murine model (Kaushal et al., 2002), and for the complete virulence (bacterial burden as well as pathology) in the non-human primate model (Mehra et al., 2012), clearly the antioxidative function promoted by $\mathrm{SigH}$ provides $M t b$ with a clear survival advantage during the innate phase of the infection (Kernodle, 2012). Several other studies point to the importance of SigH and its antioxidant function in the virulence of $M t b$. Thus, it has been established that in vivo infection in lungs of mice with $M t b$ leads to accumulation of frameshift mutations that result in a high SigH expression phenotype, and this correlates with greater virulence (Safi et al., 2019). Similarly, it has been suggested that multiplication of genome copies of SigH and the resulting increase in antioxidant activity are responsible for the ablation in the vaccine efficacy of BCG (Sadagopal et al., 2009). 
Not only is SigH critical for complete TB virulence and lung granuloma formation, but also lack of genes downstream of this key regulator results in disease ablation. Thus, a $\Delta s i g E$ mutant is also attenuated in animal models (Manganelli et al., 2001), while lack of thioredoxins or their cognate reductases results in control of infection and lack of disease (Lin et al., 2016). Similarly, the $\Delta$ sigH mutant is efficient as a vaccine in protecting both rhesus (Kaushal et al., 2015) and cynomolgus (Singh et al., in process) macaques against lethal challenge with $M t b$.

Our results therefore indicate that CSC does not cause a hypoxic influence on $M t b$ but rather generates an oxidative stress response. The high-SigH expression phenotype is clearly associated with greater virulence in multiple animal models and has been postulated to correlate with drug tolerance, treatment failure, and relapse of human TB (Safi et al., 2019). While our results were not performed in the context of $M t b$ contained within host phagocytes, they have significant implications. Induction of SigH-mediated response by CSC in $M t b$ suggests that chronic exposure to cigarette smoke may provide a pathogenic advantage to $M t b$ in individuals with pulmonary TB (which may be, in part, driven by increased sigH expression in vivo). An investigation of the effect of cigarette smoke on $M t b$ gene expression should therefore be explored in animal models of cigarette smoke exposure. This would allow controlled exposure and assessment of the effect on both host and bacteria for short-term cigarette smoke exposure. It would also be interesting to investigate the oxidative stress response of $M t b$ collected from TB patients who are long-term smokers and compare to $M t b$ from shorter-term smokers or nonsmokers.

Cigarette smoke condensate contains numerous heavy metals including cadmium, lead, copper, zinc, and selenium. The average concentrations of these metals are also higher in the blood of smokers than non-smokers (Massadeh et al., 2010). The initial induction of the copper exporter MT0997 (ctpV) at $3 \mathrm{~h}$ of CSC exposure may have caused loss of numerous metals due to non-specific metal export (Agranoff and Krishna, 2004). Since CSC contains iron and iron drives Fenton chemistry and causes oxidative stress, $\operatorname{brf} B$ upregulation at $24 \mathrm{~h}$ would prevent ironmediated oxidation, thereby protecting lipids, DNA, and proteins from the potentially toxic effects of iron (Sharma et al., 2016). The expression of copper response regulator CsoR, Rv0970, another cos response member gene, and cadI, which responds to cadmium, was also induced in $M t b$ treated with CSC.

This study indicates that the effect of cigarette smoke on the host immune response is not the only factor which is driving the link observed between smoking and TB. The effect of cigarette smoke on the bacteria themselves may very well be a driving force in the increased risk to develop TB, lack of treatment efficacy,

\section{REFERENCES}

Abdalla, A. E., Yan, S., Zeng, J., Deng, W., Xie, L., and Xie, J. (2020). Mycobacterium tuberculosis Rv0341 promotes Mycobacterium survival in in vitro hostile environments and within macrophages and induces cytokines expression. Pathogens 9:454. doi: 10.3390/pathogens9060454

Agarwal, A. R., Yin, F., and Cadenas, E. (2014). Short-term cigarette smoke exposure leads to metabolic alterations in lung alveolar cells. and increased mortality observed in smokers. This may in part occur due to cigarette smoke driving genetic mutations as well as inducing virulence factors in the bacteria, thereby allowing more effective bacterial survival.

\section{DATA AVAILABILITY STATEMENT}

The datasets presented in this study can be found in online repositories. The names of the repository/repositories and accession number(s) can be found below: https://www.ncbi.nlm. nih.gov/genbank/, GSE172041.

\section{AUTHOR CONTRIBUTIONS}

DK contributed funding and overall concept and design, and edited and wrote the manuscript. DW performed all research, conceptualized the study, analyzed the data, and wrote the manuscript. CM validated some data. SM provided resources, funding, and concept and edited and wrote the manuscript. All authors contributed to the article and approved the submitted version.

\section{FUNDING}

This work was supported by generous funding from Texas Biomed to DK. Additionally, facility grants from the NIH: P51OD011133, U42OD010442, and P51OD011104, are also acknowledged. Data for the RNA-seq were generated in the UTHSCSA Genome Sequencing Facility, which was supported by CPRIT Core Facility Award (RP160732). Data analysis services were also provided by the Texas Biomedical Research Institute Molecular Services Core, which was supported and subsidized by institutional resources.

\section{ACKNOWLEDGMENTS}

We would like to acknowledge Clinton Christensen and Jeremy Glenn at the Texas Biomedical Research Institute Molecular Services Core, for preparing the libraries and depleting ribosomal RNA for the RNA-seq experiments. We would also like to acknowledge Anna Allué Garcia for valuable advice regarding RNA extractions and differential gene expression analysis and Stuart Meier for valuable advice regarding statistical analyses. Valuable lab management by Journey Cole and administrative assistance by Helen Hawn are also acknowledged.

Am. J. Respir. Cell Mol. Biol. 51, 284-293. doi: 10.1165/rcmb.2013-0 $523 \mathrm{OC}$

Agranoff, D., and Krishna, S. (2004). Metal ion transport and regulation in Mycobacterium tuberculosis. Front. Biosci. 9:2996-3006. doi: 10.2741/ 1454

Agren, D., Schnell, R., Oehlmann, W., Singh, M., and Schneider, G. (2008). Cysteine synthase (CysM) of Mycobacterium tuberculosis is an O-phosphoserine sulfhydrylase: evidence for an alternative cysteine 
biosynthesis pathway in mycobacteria. J. Biol. Chem. 283, 31567-31574. doi: 10.1074/jbc.M804877200

Akif, M., Khare, G., Tyagi, A. K., Mande, S. C., and Sardesai, A. A. (2008). Functional studies of multiple thioredoxins from Mycobacterium tuberculosis. J. Bacteriol. 190, 7087-7095. doi: 10.1128/JB.00 159-08

Alderwick, L. J., Birch, H. L., Mishra, A. K., Eggeling, L., and Besra, G. S. (2007). Structure, function and biosynthesis of the Mycobacterium tuberculosis cell wall: arabinogalactan and lipoarabinomannan assembly with a view to discovering new drug targets. Biochem. Soc. Trans. 35(Pt 5), 1325-1328. doi: 10.1042/ BST0351325

Alexandrov, L. B., Kim, J., Haradhvala, N. J., Huang, M. N., Tian Ng, A. W., Wu, Y., et al. (2020). The repertoire of mutational signatures in human cancer. Nature 578, 94-101. doi: 10.1038/s41586-020-1943-3

Arumugam, P., Shankaran, D., Bothra, A., Gandotra, S., and Rao, V. (2019). The MmpS6-MmpL6 operon is an oxidative stress response system providing selective advantage to Mycobacterium tuberculosis in Stress. J. Infect. Dis. 219, 459-469. doi: 10.1093/infdis/jiy526

Aryanpur, M., Masjedi, M. R., Mortaz, E., Hosseini, M., Jamaati, H., Tabarsi, P., et al. (2016a). Intention to quit smoking and associated factors in smokers newly diagnosed with pulmonary tuberculosis. Tanaffos 15, 17-24.

Aryanpur, M., Mortaz, E., Masjedi, M. R., Tabarsi, P., Garssen, J., Adcock, I. M., et al. (2016b). Reduced phagocytic capacity of blood monocyte/macrophages in tuberculosis patients is further reduced by smoking. Iran. J. Allergy Asthma Immunol. 15, 174-182.

Aufderheide, M., and Gressmann, H. (2007). A modified Ames assay reveals the mutagenicity of native cigarette mainstream smoke and its gas vapour phase. Exp. Toxicol. Pathol. 58, 383-392. doi: 10.1016/j.etp.2007.02.002

Aufderheide, M., and Gressmann, H. (2008). Mutagenicity of native cigarette mainstream smoke and its gas/vapour phase by use of different tester strains and cigarettes in a modified Ames assay. Mutat. Res. 656, 82-87. doi: 10.1016/j. mrgentox.2008.07.008

Av-Gay, Y., and Everett, M. (2000). The eukaryotic-like Ser/Thr protein kinases of Mycobacterium tuberculosis. Trends Microbiol. 8, 238-244.

Baboni, F. B., Guariza Filho, O., Moreno, A. N., and Rosa, E. A. R. (2010). Influence of cigarette smoke condensate on cariogenic and candidal biofilm formation on orthodontic materials. Am. J. Orthod. Dentofacial Orthop. 138, 427-434. doi: 10.1016/j.ajodo.2009.05.023

Bacon, J., James, B. W., Wernisch, L., Williams, A., Morley, K. A., Hatch, G. J., et al. (2004). The influence of reduced oxygen availability on pathogenicity and gene expression in Mycobacterium tuberculosis. Tuberculosis (Edinb.). 84, 205-217. doi: 10.1016/j.tube.2003.12.011

Bai, J. W., Chen, X. X., Liu, S., Yu, L., and Xu, J. F. (2017). Smoking cessation affects the natural history of COPD. Int. J. Chron. Obstruct. Pulmon. Dis. 12, 3323-3328. doi: 10.2147/COPD.S150243

Bandyopadhyay, B., Das Gupta, T., Roy, D., and Das Gupta, S. K. (2012). DnaK dependence of the mycobacterial stress-responsive regulator $\mathrm{HspR}$ is mediated through its hydrophobic C-terminal tail. J. Bacteriol. 194, 4688-4697. doi: 10. 1128/JB.00415-12

Becker, S. H., Ulrich, K., Dhabaria, A., Ueberheide, B., Beavers, W., Skaar, E. P., et al. (2020). Mycobacterium tuberculosis Rv0991c Is a Redox-Regulated Molecular Chaperone. mBio 11, e1545-e1520. doi: 10.1128/mBio.01545-20

Bolla, J. R., Do, S. V., Long, F., Dai, L., Su, C. C., Lei, H. T., et al. (2012). Structural and functional analysis of the transcriptional regulator Rv3066 of Mycobacterium tuberculosis. Nucleic Acids Res. 40, 9340-9355. doi: 10.1093/nar/ gks677

Bonacci, R. A., Cruz-Hervert, L. P., Garcia-Garcia, L., Reynales-Shigematsu, L. M., Ferreyra-Reyes, L., Bobadilla-del-Valle, M., et al. (2013). Impact of cigarette smoking on rates and clinical prognosis of pulmonary tuberculosis in Southern Mexico. J. Infect. 66, 303-312. doi: 10.1016/j.jinf.2012.09.005

Borgerding, M., and Klus, H. (2005). Analysis of complex mixtures-cigarette smoke. Exp. Toxicol. Pathol. 57(Suppl. 1), 43-73. doi: 10.1016/j.etp.2005.05.010

Boshoff, H. I., Reed, M. B., Barry, C. E. III, and Mizrahi, V. (2003). DnaE2 polymerase contributes to in vivo survival and the emergence of drug resistance in Mycobacterium tuberculosis. Cell 113, 183-193. doi: 10.1016/s0092-8674(03) 00270-8

Bourgeois, J. S., Jacob, J., Garewal, A., Ndahayo, R., and Paxson, J. (2016). The bioavailability of soluble cigarette smoke extract is reduced through interactions with cells and affects the cellular response to CSE exposure. PLoS One 11:e0163182. doi: 10.1371/journal.pone.0163182

Bronner Murrison, L., Martinson, N., Moloney, R. M., Msandiwa, R., Mashabela, M., Samet, J. M., et al. (2016). Tobacco smoking and tuberculosis among men living with HIV in Johannesburg, South Africa: a case-control study. PLoS One 11:e0167133. doi: 10.1371/journal.pone.0167133

Camoirano, A., Balansky, R. M., Bennicelli, C., Izzotti, A., D’Agostini, F., and De Flora, S. (1994). Experimental databases on inhibition of the bacterial mutagenicity of 4-nitroquinoline 1-oxide and cigarette smoke. Mutat. Res. 317, 89-109. doi: 10.1016/0165-1110(94)90019-1

Chapeton-Montes, J. A., Plaza, D. F., Curtidor, H., Forero, M., Vanegas, M., Patarroyo, M. E., et al. (2008). Characterizing the Mycobacterium tuberculosis Rv2707 protein and determining its sequences which specifically bind to two human cell lines. Protein Sci. 17, 342-351. doi: 10.1110/ps.073083308

Charlson, E. S., Chen, J., Custers-Allen, R., Bittinger, K., Li, H., Sinha, R., et al. (2010). Disordered microbial communities in the upper respiratory tract of cigarette smokers. PLoS One 5:e15216. doi: 10.1371/journal.pone.0015216

Chen, C., Han, X., Yan, Q., Wang, C., Jia, L., Taj, A., et al. (2019). The inhibitory effect of GlmU acetyltransferase inhibitor TPSA on Mycobacterium tuberculosis may be affected due to its methylation by methyltransferase Rv0560c. Front. Cell. Infect. Microbiol. 9:251. doi: 10.3389/fcimb.2019.00251

Chiang, Y. C., Lin, Y. M., Lee, J. A., Lee, C. N., and Chen, H. Y. (2012). Tobacco consumption is a reversible risk factor associated with reduced successful treatment outcomes of anti-tuberculosis therapy. Int J Infect Dis. 16, e130-e135. doi: 10.1016/j.ijid.2011.10.007

Chien, J., Hwang, J. H., Nilaad, S., Masso-Silva, J. A., Jeong, Ahn S, McEachern, E. K., et al. (2020). Cigarette smoke exposure promotes virulence of Pseudomonas aeruginosa and induces resistance to neutrophil killing. Infect. Immun. 88:e00527-20. doi: 10.1128/IAI.00527-20

Cholo, M. C., Rasehlo, S. S. M., Venter, E., Venter, C., and Anderson, R. (2020). Effects of cigarette smoke condensate on growth and biofilm formation by Mycobacterium tuberculosis. Biomed. Res. Int. 2020:8237402. doi: 10.1155/2020/ 8237402

Claxton, L. D., Morin, R. S., Hughes, T. J., and Lewtas, J. (1989). A genotoxic assessment of environmental tobacco smoke using bacterial bioassays. Mutat. Res. 222, 81-99. doi: 10.1016/0165-1218(89)90022-0

Cockeran, R., Herbert, J. A., Mitchell, T. J., Dix-Peek, T., Dickens, C., Anderson, R., et al. (2014). Exposure of a 23F serotype strain of Streptococcus pneumoniae to cigarette smoke condensate is associated with selective upregulation of genes encoding the two-component regulatory system 11 (TCS11). Biomed. Res. Int. 2014:976347. doi: 10.1155/2014/976347

Coulson, G. B., Johnson, B. K., Zheng, H., Colvin, C. J., Fillinger, R. J., Haiderer, E. R., et al. (2017). Targeting Mycobacterium tuberculosis sensitivity to thiol stress at acidic $\mathrm{pH}$ kills the bacterium and potentiates antibiotics. Cell Chem. Biol. 24, 993-1004.e4. doi: 10.1016/j.chembiol.2017.06.018

Crotty Alexander, L. E., Drummond, C. A., Hepokoski, M., Mathew, D., Moshensky, A., Willeford, A., et al. (2018). Chronic inhalation of e-cigarette vapor containing nicotine disrupts airway barrier function and induces systemic inflammation and multiorgan fibrosis in mice. Am. J. Physiol. Regul. Integr. Comp. Physiol. 314, R834-R847. doi: 10.1152/ajpregu.00270.2017

Crotty Alexander, L. E., Vyas, A., Schraufnagel, D. E., and Malhotra, A. (2015). Electronic cigarettes: the new face of nicotine delivery and addiction. J. Thorac. Dis. 7, E248-E251. doi: 10.3978/j.issn.2072-1439.2015.07.37

De Rossi, E., Arrigo, P., Bellinzoni, M., Silva, P. A., Martin, C., Ainsa, J. A., et al. (2002). The multidrug transporters belonging to major facilitator superfamily in Mycobacterium tuberculosis. Mol. Med. 8, 714-724.

Feng, Y., Kong, Y., Barnes, P. F., Huang, F. F., Klucar, P., Wang, X., et al. (2011). Exposure to cigarette smoke inhibits the pulmonary T-cell response to influenza virus and Mycobacterium tuberculosis. Infect. Immun. 79, 229-237. doi: 10.1128/IAI.00709-10

Festa, R. A., Jones, M. B., Butler-Wu, S., Sinsimer, D., Gerads, R., Bishai, W. R., et al. (2011). A novel copper-responsive regulon in Mycobacterium tuberculosis. Mol. Microbiol. 79, 133-148. doi: 10.1111/j.1365-2958.2010.07431.x

Ford, C. B., Shah, R. R., Maeda, M. K., Gagneux, S., Murray, M. B., Cohen, T., et al. (2013). Mycobacterium tuberculosis mutation rate estimates from different lineages predict substantial differences in the emergence of drug-resistant tuberculosis. Nat. Genet. 45, 784-790. doi: 10.1038/ng.2656 
Frenoy, A., and Bonhoeffer, S. (2018). Death and population dynamics affect mutation rate estimates and evolvability under stress in bacteria. PLoS Biol. 16:e2005056. doi: 10.1371/journal.pbio.2005056

Ge, S. X., Son, E. W., and Yao, R. (2018). iDEP: an integrated web application for differential expression and pathway analysis of RNA-Seq data. BMC Bioinformatics 19:534. doi: 10.1186/s12859-018-2486-6

Gey van Pittius, N. C., Sampson, S. L., Lee, H., Kim, Y., van Helden, P. D., and Warren, R. M. (2006). Evolution and expansion of the Mycobacterium tuberculosis PE and PPE multigene families and their association with the duplication of the ESAT-6 (esx) gene cluster regions. BMC Evol. Biol. 6:95. doi: 10.1186/1471-2148-6-95

Gold, B., Deng, H., Bryk, R., Vargas, D., Eliezer, D., Roberts, J., et al. (2008). Identification of a copper-binding metallothionein in pathogenic mycobacteria. Nat. Chem. Biol. 4, 609-616. doi: 10.1038/nchembio.109

Goldstein-Daruech, N., Cope, E. K., Zhao, K. Q., Vukovic, K., Kofonow, J. M., Doghramji, L., et al. (2011). Tobacco smoke mediated induction of sinonasal microbial biofilms. PLoS One. 6:e15700. doi: 10.1371/journal.pone.0015700

Greenstein, R. J., Su, L., and Brown, S. T. (2011). Growth of M. avium subspecies paratuberculosis in culture is enhanced by nicotinic acid, nicotinamide, and alpha and beta nicotinamide adenine dinucleotide. Dig. Dis. Sci. 56, 368-375. doi: $10.1007 / \mathrm{s} 10620-010-1301-7$

Hirano, K., Abe, C., and Takahashi, M. (1999). Mutations in the rpoB gene of rifampin-resistant Mycobacterium tuberculosis strains isolated mostly in Asian countries and their rapid detection by line probe assay. J. Clin. Microbiol. 37, 2663-2666. doi: 10.1128/JCM.37.8.2663-2666.1999

Hotter, G. S., Wilson, T., and Collins, D. M. (2001). Identification of a cadmiuminduced gene in Mycobacterium bovis and Mycobacterium tuberculosis. FEMS Microbiol. Lett. 200, 151-155. doi: 10.1111/j.1574-6968.2001.tb10707.x

Hwang, J. H., Lyes, M., Sladewski, K., Enany, S., McEachern, E., Mathew, D. P., et al. (2016). Electronic cigarette inhalation alters innate immunity and airway cytokines while increasing the virulence of colonizing bacteria. J. Mol. Med. (Berl.). 94, 667-679. doi: 10.1007/s00109-016-1378-3

Hwang, J. Y., Randall, T. D., and Silva-Sanchez, A. (2016). Inducible bronchusassociated lymphoid tissue: taming inflammation in the lung. Front. Immunol. 7:258. doi: 10.3389/fimmu. 2016.00258

Jha, P., Jacob, B., Gajalakshmi, V., Gupta, P. C., Dhingra, N., Kumar, R., et al. (2008). A nationally representative case-control study of smoking and death in India. N. Engl. J. Med. 358, 1137-1147. doi: 10.1056/NEJMsa0707719

Johnston, J. B., Ouellet, H., and Ortiz de Montellano, P. R. (2010). Functional redundancy of steroid C26-monooxygenase activity in Mycobacterium tuberculosis revealed by biochemical and genetic analyses. J. Biol. Chem. 285, 36352-36360. doi: 10.1074/jbc.M110.161117

Kana, B. D., Abrahams, G. L., Sung, N., Warner, D. F., Gordhan, B. G., Machowski, E. E., et al. (2010). Role of the DinB homologs Rv1537 and Rv3056 in Mycobacterium tuberculosis. J. Bacteriol. 192, 2220-2227. doi: 10.1128/JB. 01135-09

Karboul, A., Mazza, A., Gey van Pittius, N. C., Ho, J. L., Brousseau, R., and Mardassi, H. (2008). Frequent homologous recombination events in Mycobacterium tuberculosis PE/PPE multigene families: potential role in antigenic variability. J. Bacteriol. 190, 7838-7846. doi: 10.1128/JB.00827-08

Kaushal, D., Foreman, T. W., Gautam, U. S., Alvarez, X., Adekambi, T., RangelMoreno, J., et al. (2015). Mucosal vaccination with attenuated Mycobacterium tuberculosis induces strong central memory responses and protects against tuberculosis. Nat. Commun. 6:8533. doi: 10.1038/ncomms 9533

Kaushal, D., Schroeder, B. G., Tyagi, S., Yoshimatsu, T., Scott, C., Ko, C., et al. (2002). Reduced immunopathology and mortality despite tissue persistence in a Mycobacterium tuberculosis mutant lacking alternative sigma factor, SigH. Proc. Natl. Acad. Sci. U. S. A. 99, 8330-8335. doi: 10.1073/pnas.102055799

Kernodle, D. S. (2012). SigH, antioxidants, and the pathogenesis of pulmonary tuberculosis. J. Infect. Dis. 205, 1186-1188. doi: 10.1093/infdis/jis108

Kim, Y. H., An, Y. J., Jo, S., Lee, S. H., Lee, S. J., Choi, S. J., et al. (2018). Comparison of volatile organic compounds between cigarette smoke condensate (CSC) and extract (CSE) samples. Environ. Health Toxicol. 33:e2018012. doi: 10.5620/eht. e2018012

Kulkarni, R., Antala, S., Wang, A., Amaral, F. E., Rampersaud, R., Larussa, S. J., et al. (2012). Cigarette smoke increases Staphylococcus aureus biofilm formation via oxidative stress. Infect. Immun. 80, 3804-3811. doi: 10.1128/IAI. 00689-12
Kulkarni, R., Caskey, J., Singh, S. K., Paudel, S., Baral, P., Schexnayder, M., et al. (2016). Cigarette smoke extract-exposed methicillin-resistant Staphylococcus aureus regulates leukocyte function for pulmonary persistence. Am. J. Respir. Cell. Mol. Biol. 55, 586-601. doi: 10.1165/rcmb.2015-0397OC

Lee, J. H., Karakousis, P. C., and Bishai, W. R. (2008). Roles of SigB and SigF in the Mycobacterium tuberculosis sigma factor network. J. Bacteriol. 190, 699-707. doi: 10.1128/JB.01273-07

Lee, S. J., Lee, I. G., Lee, K. Y., Kim, D. G., Eun, H. J., Yoon, H. J., et al. (2016). Two distinct mechanisms of transcriptional regulation by the redox sensor YodB. Proc. Natl. Acad. Sci. U. S. A. 113, E5202-E5211. doi: 10.1073/pnas. 160442 7113

Lin, H. H., Ezzati, M., Chang, H. Y., and Murray, M. (2009). Association between tobacco smoking and active tuberculosis in Taiwan: prospective cohort study. Am. J. Respir. Crit. Care Med. 180, 475-480. doi: 10.1164/rccm.200904-0549OC

Lin, K., O’Brien, K. M., Trujillo, C., Wang, R., Wallach, J. B., Schnappinger, D., et al. (2016). Mycobacterium tuberculosis thioredoxin reductase is essential for thiol redox homeostasis but plays a minor role in antioxidant defense. PLoS Pathog. 12:e1005675. doi: 10.1371/journal.ppat.1005675

Liu, T., Ramesh, A., Ma, Z., Ward, S. K., Zhang, L., George, G. N., et al. (2007). CsoR is a novel Mycobacterium tuberculosis copper-sensing transcriptional regulator. Nat. Chem. Biol. 3, 60-68. doi: 10.1038/nchembio844

Manganelli, R., Voskuil, M. I., Schoolnik, G. K., Dubnau, E., Gomez, M., and Smith, I. (2002). Role of the extracytoplasmic-function sigma factor sigma(H) in Mycobacterium tuberculosis global gene expression. Mol. Microbiol. 45, 365-374.

Manganelli, R., Voskuil, M. I., Schoolnik, G. K., and Smith, I. (2001). The Mycobacterium tuberculosis ECF sigma factor sigmaE: role in global gene expression and survival in macrophages. Mol. Microbiol. 41, 423-437. doi: 10.1046/j.1365-2958.2001.02525.x

Manna, S., Waring, A., Papanicolaou, A., Hall, N. E., Bozinovski, S., Dunne, E. M., et al. (2018). The transcriptomic response of Streptococcus pneumoniae following exposure to cigarette smoke extract. Sci. Rep. 8:15716. doi: 10.1038/ s41598-018-34103-5

Mashalidis, E. H., Mukherjee, T., Sledz, P., Matak-Vinkovic, D., Boshoff, H., Abell, C., et al. (2011). Rv2607 from Mycobacterium tuberculosis is a pyridoxine $5^{\prime}-$ phosphate oxidase with unusual substrate specificity. PLoS One 6:e27643. doi: 10.1371/journal.pone. 0027643

Massadeh, A., Gharibeh, A., Omari, K., Al-Momani, I., Alomary, A., Tumah, H., et al. (2010). Simultaneous determination of $\mathrm{Cd}, \mathrm{Pb}, \mathrm{Cu}, \mathrm{Zn}$, and $\mathrm{Se}$ in human blood of jordanian smokers by ICP-OES. Biol. Trace Elem. Res. 133, 1-11. doi: 10.1007/s12011-009-8405-y

McEachern, E. K., Hwang, J. H., Sladewski, K. M., Nicatia, S., Dewitz, C., Mathew, D. P., et al. (2015). Analysis of the effects of cigarette smoke on staphylococcal virulence phenotypes. Infect. Immun. 83, 2443-2452. doi: 10.1128/IAI.00 303-15

McGrath, M., Gey van Pittius, N. C., van Helden, P. D., Warren, R. M., and Warner, D. F. (2014). Mutation rate and the emergence of drug resistance in Mycobacterium tuberculosis. J. Antimicrob. Chemother. 69, 292-302. doi: $10.1093 / \mathrm{jac} / \mathrm{dkt} 364$

Mehra, S., Foreman, T. W., Didier, P. J., Ahsan, M. H., Hudock, T. A., Kissee, R., et al. (2015). The DosR regulon modulates adaptive immunity and is essential for M. tuberculosis persistence. Am. J. Respir. Crit. Care Med. 191, 1185-1196. doi: $10.1164 / \mathrm{rccm} .201408-1502 \mathrm{OC}$

Mehra, S., Golden, N. A., Stuckey, K., Didier, P. J., Doyle, L. A., Russell-Lodrigue, K. E., et al. (2012). The Mycobacterium tuberculosis stress response factor SigH is required for bacterial burden as well as immunopathology in primate lungs. J. Infect. Dis. 205, 1203-1213. doi: 10.1093/infdis/jis102

Mehra, S., and Kaushal, D. (2009). Functional genomics reveals extended roles of the Mycobacterium tuberculosis stress response factor sigmaH. J. Bacteriol. 191, 3965-3980. doi: 10.1128/JB.00064-09

Melief, E., Bonnett, S. A., Zuniga, E. S., and Parish, T. (2019). Activation of 2,4-diaminoquinazoline in Mycobacterium tuberculosis by Rv3161c, a putative dioxygenase. Antimicrob. Agents Chemother. 63:e01505-18. doi: 10.1128/AAC. 01505-18

Miramontes, C. V., Rodriguez-Carlos, A., Marin-Luevano, S. P., Trejo Martinez, L. A., de Haro Acosta, J., Enciso-Moreno, J. A., et al. (2021). Nicotine promotes the intracellular growth of Mycobacterium tuberculosis in epithelial cells. Tuberculosis (Edinb.). 127:102026. doi: 10.1016/j.tube.2020.102026 
Miyahara, E., Nishie, M., Takumi, S., Miyanohara, H., Nishi, J., Yoshiie, K., et al. (2011). Environmental mutagens may be implicated in the emergence of drugresistant microorganisms. FEMS Microbiol. Lett. 317, 109-116. doi: 10.1111/j. 1574-6968.2011.02215.x

Mizusaki, S., Okamoto, H., Akiyama, A., and Fukuhara, Y. (1977). Relation between chemical constituents of tobacco and mutagenic activity of cigarette smoke condensate. Mutat. Res. 48, 319-325. doi: 10.1016/0027-5107(77)90 175-0

Morin, R. S., Tulis, J. J., and Claxton, L. D. (1987). The effect of solvent and extraction methods on the bacterial mutagenicity of sidestream cigarette smoke. Toxicol. Lett. 38, 279-290. doi: 10.1016/0378-4274(87)90010-5

Murphy, D. J., and Brown, J. R. (2007). Identification of gene targets against dormant phase Mycobacterium tuberculosis infections. BMC Infect. Dis. 7:84. doi: 10.1186/1471-2334-7-84

Mutepe, N. D., Cockeran, R., Steel, H. C., Theron, A. J., Mitchell, T. J., Feldman, C., et al. (2013). Effects of cigarette smoke condensate on pneumococcal biofilm formation and pneumolysin. Eur. Respir. J. 41, 392-395. doi: 10.1183/09031936. 00213211

Naz, S., Dabral, S., Nagarajan, S. N., Arora, D., Singh, L. V., Kumar, P., et al. (2021). Compromised base excision repair pathway in Mycobacterium tuberculosis imparts superior adaptability in the host. PLoS Pathog. 17:e1009452. doi: 10. 1371/journal.ppat.1009452

O'Leary, S. M., Coleman, M. M., Chew, W. M., Morrow, C., McLaughlin, A. M., Gleeson, L. E., et al. (2014). Cigarette smoking impairs human pulmonary immunity to Mycobacterium tuberculosis. Am. J. Respir. Crit. Care Med. 190, 1430-1436. doi: 10.1164/rccm.201407-1385OC

Olson, A. L., Neumann, T. S., Cai, S., and Sem, D. S. (2013). Solution structures of Mycobacterium tuberculosis thioredoxin C and models of intact thioredoxin system suggest new approaches to inhibitor and drug design. Proteins 81, 675-689. doi: 10.1002/prot.24228

Ozturk, A. B., Kilicaslan, Z., and Issever, H. (2014). Effect of smoking and indoor air pollution on the risk of tuberculosis: smoking, indoor air pollution and tuberculosis. Tuberk. Toraks. 62, 1-6. doi: 10.5578/tt.7013

Perez, E., Constant, P., Laval, F., Lemassu, A., Laneelle, M. A., Daffe, M., et al. (2004). Molecular dissection of the role of two methyltransferases in the biosynthesis of phenolglycolipids and phthiocerol dimycoserosate in the Mycobacterium tuberculosis complex. J. Biol. Chem. 279, 42584-42592. doi: 10.1074/jbc.M406134200

Phong, T. Q., Ha do, T. T., Volker, U., and Hammer, E. (2015). Using a label free quantitative proteomics approach to identify changes in protein abundance in multidrug-resistant Mycobacterium tuberculosis. Indian J. Microbiol. 55, 219-230. doi: 10.1007/s12088-015-0511-2

Poole, K., and Fruci, M. (2016). "Antimicrobial drug efflux systems as components of bacterial stress responses," in Efflux-Mediated Antimicrobial Resistance in Bacteria, eds X. Z. Li, C. Elkins, and H. Zgurskaya (Cham: Adis). doi: 10.1007/ 978-3-319-39658-3_26

Radhakrishnan, A., Kumar, N., Wright, C. C., Chou, T. H., Tringides, M. L., Bolla, J. R., et al. (2014). Crystal structure of the transcriptional regulator Rv0678 of Mycobacterium tuberculosis. J. Biol. Chem. 289, 16526-16540. doi: 10.1074/jbc. M113.538959

Rahlwes, K. C., Osman, S. H., and Morita, Y. S. (2020). Role of LmeA, a mycobacterial periplasmic protein, in maintaining the mannosyltransferase MptA and its product Lipomannan under stress. mSphere 5:e01039-20. doi: 10.1128/mSphere.01039-20

Rao, V. G., Bhat, J., Yadav, R., Muniyandi, M., Bhondeley, M. K., and Wares, D. F. (2017). Smoking and alcohol consumption: risk factors for pulmonary tuberculosis among the tribal community in central India. Indian J. Tuberc. 64, 40-43. doi: 10.1016/j.ijtb.2016.11.009

Rao, V. G., Gopi, P. G., Bhat, J., Yadav, R., Selvakumar, N., and Wares, D. F. (2012). Selected risk factors associated with pulmonary tuberculosis among Saharia tribe of Madhya Pradesh, central India. Eur. J. Public Health 22, 271-273. doi: 10.1093/eurpub/ckr009

Reyes, A., Sandoval, A., Cubillos-Ruiz, A., Varley, K. E., Hernandez-Neuta, I., Samper, S., et al. (2012). IS-seq: a novel high throughput survey of in vivo IS6110 transposition in multiple Mycobacterium tuberculosis genomes. BMC Genomics 13:249. doi: 10.1186/1471-2164-13-249

Roemer, E., Meisgen, T., Diekmann, J., Conroy, L., and Stabbert, R. (2016). Heterocyclic aromatic amines and their contribution to the bacterial mutagenicity of the particulate phase of cigarette smoke. Toxicol. Lett. 243, 40-47. doi: 10.1016/j.toxlet.2015.12.008

Rowland, J. L., and Niederweis, M. (2012). Resistance mechanisms of Mycobacterium tuberculosis against phagosomal copper overload. Tuberculosis (Edinb.). 92, 202-210. doi: 10.1016/j.tube.2011. 12.006

Sadagopal, S., Braunstein, M., Hager, C. C., Wei, J., Daniel, A. K., Bochan, M. R., et al. (2009). Reducing the activity and secretion of microbial antioxidants enhances the immunogenicity of BCG. PLoS One 4:e5531. doi: 10.1371/journal. pone. 0005531

Safi, H., Gopal, P., Lingaraju, S., Ma, S., Levine, C., Dartois, V., et al. (2019). Phase variation in Mycobacterium tuberculosis glpK produces transiently heritable drug tolerance. Proc. Natl. Acad. Sci. U. S. A. 116, 19665-19674. doi: 10.1073/ pnas. 1907631116

Semlali, A., Killer, K., Alanazi, H., Chmielewski, W., and Rouabhia, M. (2014). Cigarette smoke condensate increases C. albicans adhesion, growth, biofilm formation, and EAP1, HWP1 and SAP2 gene expression. BMC Microbiol. 14:61. doi: 10.1186/1471-2180-14-61

Shaler, C. R., Horvath, C. N., McCormick, S., Jeyanathan, M., Khera, A., Zganiacz, A., et al. (2013). Continuous and discontinuous cigarette smoke exposure differentially affects protective Th1 immunity against pulmonary tuberculosis. PLoS One 8:e59185. doi: 10.1371/journal.pone.0059185

Sharma, D., Lata, M., Faheem, M., Khan, A. U., Joshi, B., Venkatesan, K., et al. (2016). M. tuberculosis ferritin (Rv3841): potential involvement in Amikacin (AK) \& Kanamycin (KM) resistance. Biochem. Biophys. Res. Commun. 478, 908-912. doi: 10.1016/j.bbrc.2016.08.049

Smith, G. S., Van Den Eeden, S. K., Baxter, R., Shan, J., Van Rie, A., Herring, A. H., et al. (2015). Cigarette smoking and pulmonary tuberculosis in northern California. J. Epidemiol. Commun. Health 69, 568-573. doi: 10.1136/jech-2014204292

Soni, D. K., Dubey, S. K., and Bhatnagar, R. (2020). ATP-binding cassette (ABC) import systems of Mycobacterium tuberculosis: target for drug and vaccine development. Emerg. Microbes Infect. 9, 207-220. doi: 10.1080/22221751.2020. 1714488

Stampfli, M. R., and Anderson, G. P. (2009). How cigarette smoke skews immune responses to promote infection, lung disease and cancer. Nat. Rev. Immunol. 9, 377-384. doi: 10.1038/nri2530

Sun, X., Zhang, L., Jiang, J., Ng, M., Cui, Z., Mai, J., et al. (2018). Transcription factors Rv0081 and Rv3334 connect the early and the enduring hypoxic response of Mycobacterium tuberculosis. Virulence 9, 1468-1482. doi: 10.1080/ 21505594.2018.1514237

Sutcliffe, I. C., and Harrington, D. J. (2004). Lipoproteins of Mycobacterium tuberculosis: an abundant and functionally diverse class of cell envelope components. FEMS Microbiol. Rev. 28, 645-659. doi: 10.1016/j.femsre.2004.06. 002

Thakur, K. G., Joshi, A. M., and Gopal, B. (2007). Structural and biophysical studies on two promoter recognition domains of the extra-cytoplasmic function sigma factor sigma(C) from Mycobacterium tuberculosis. J. Biol. Chem. 282, 4711-4718. doi: 10.1074/jbc.M606283200

Thorne, D., Crooks, I., Hollings, M., Seymour, A., Meredith, C., and Gaca, M. (2016). The mutagenic assessment of an electronic-cigarette and reference cigarette smoke using the Ames assay in strains TA98 and TA100. Mutat. Res. 812, 29-38. doi: 10.1016/j.mrgentox.2016.10.005

Tripathi, P., Singh, L. K., Kumari, S., Hakiem, O. R., and Batra, J. K. (2020). $\mathrm{ClpB}$ is an essential stress regulator of Mycobacterium tuberculosis and endows survival advantage to dormant bacilli. Int. J. Med. Microbiol. 310:151402. doi: 10.1016/j.ijmm.2020.151402

Tyagi, P., Dharmaraja, A. T., Bhaskar, A., Chakrapani, H., and Singh, A. (2015). Mycobacterium tuberculosis has diminished capacity to counteract redox stress induced by elevated levels of endogenous superoxide. Free Radic. Biol. Med. 84, 344-354. doi: 10.1016/j.freeradbiomed.2015.03.008

Voskuil, M. I., Bartek, I. L., Visconti, K., and Schoolnik, G. K. (2011). The response of mycobacterium tuberculosis to reactive oxygen and nitrogen species. Front. Microbiol. 2:105. doi: 10.3389/fmicb.2011.00105

Voss, M., Nimtz, M., and Leimkuhler, S. (2011). Elucidation of the dual role of mycobacterial MoeZR in molybdenum cofactor biosynthesis and cysteine biosynthesis. PLoS One 6:e28170. doi: 10.1371/journal.pone.002 8170 
Ward, S. K., Abomoelak, B., Hoye, E. A., Steinberg, H., and Talaat, A. M. (2010). CtpV: a putative copper exporter required for full virulence of Mycobacterium tuberculosis. Mol. Microbiol. 77, 1096-1110. doi: 10.1111/j.1365-2958.2010. 07273.x

Wayne, L. G., and Hayes, L. G. (1996). An in vitro model for sequential study of shiftdown of Mycobacterium tuberculosis through two stages of nonreplicating persistence. Infect. Immun. 64, 2062-2069.

WHO (2019). New Data on Tuberculosis Trends in 202 Countries. Available online at: https://www.who.int/teams/global-tuberculosis-programme/tb-reports/ global-report-2019

Wohlkonig, A., Remaut, H., Moune, M., Tanina, A., Meyer, F., Desroses, M., et al. (2017). Structural analysis of the interaction between spiroisoxazoline SMARt-420 and the Mycobacterium tuberculosis repressor EthR2. Biochem. Biophys. Res. Commun. 487, 403-408. doi: 10.1016/j.bbrc.2017. 04.074

Yim, J. J., Yoo, C. G., Lee, C. T., Kim, Y. W., Han, S. K., and Shim, Y. S. (2002). Lack of association between glutathione S-transferase P1 polymorphism and COPD in Koreans. Lung 180, 119-125. doi: 10.1007/s004080000086

Yim, S. H., and Hee, S. S. (2001). Bacterial mutagenicity of some tobacco aromatic nitrogen bases and their mixtures. Mutat. Res. 492, 13-27. doi: 10.1016/s13835718(01)00152-8

Yu, G., Phillips, S., Gail, M. H., Goedert, J. J., Humphrys, M. S., Ravel, J., et al. (2017). The effect of cigarette smoking on the oral and nasal microbiota. Microbiome 5:3. doi: 10.1186/s40168-016-0226-6
Yu, G. P., Hsieh, C. C., and Peng, J. (1988). Risk factors associated with the prevalence of pulmonary tuberculosis among sanitary workers in Shanghai. Tubercle 69, 105-112. doi: 10.1016/0041-3879(88)9 0072-4

Zeng, L., Shi, T., Zhao, Q., and Xie, J. (2013). Mycobacterium sulfur metabolism and implications for novel drug targets. Cell Biochem. Biophys. 65, 77-83. doi: $10.1007 /$ s 12013-012-9410-x

Conflict of Interest: The authors declare that the research was conducted in the absence of any commercial or financial relationships that could be construed as a potential conflict of interest.

Publisher's Note: All claims expressed in this article are solely those of the authors and do not necessarily represent those of their affiliated organizations, or those of the publisher, the editors and the reviewers. Any product that may be evaluated in this article, or claim that may be made by its manufacturer, is not guaranteed or endorsed by the publisher.

Copyright (C) 2021 Willemse, Moodley, Mehra and Kaushal. This is an open-access article distributed under the terms of the Creative Commons Attribution License (CC BY). The use, distribution or reproduction in other forums is permitted, provided the original author(s) and the copyright owner(s) are credited and that the original publication in this journal is cited, in accordance with accepted academic practice. No use, distribution or reproduction is permitted which does not comply with these terms. 